\title{
Put your Hand on My Shoulder: Miracle of Mind Over Body
}

\author{
Deepak Shimkhada* \\ Claremont School of Theology, USA
}

Submission: June 20, 2019; Published: July 03, 2019

*Corresponding author: Deepak Shimkhada, Claremont School of Theology, USA

Abstract

After having open heart surgery, Mr. Zee was sent to the cardiac rehab centre by his doctor. Upon reviewing his health history and present heart condition, the nurse developed a six-week plan for him to follow. According to the regimen, he was to go on a treadmill for 40 minutes, among other cardiac-related exercises such as bicycling, rowing, stretching, etc.

Keywords: Exercise performances; Monitoring centre; Cardiac-related exercises; Bicycling, Rowing, Stretching

\section{Opinion}

In the first week, she had him walk slowly at two miles per hour, a speed appropriate for his condition. Then she gradually increased the speed to 2.5 . On the third week, he was at 2.8. Then on the fourth week, he was doing three miles per hour. This was marked progress considering the condition he had been in four weeks earlier. By now, he was getting stronger and feeling high energy and he wanted to get back to work, selling homes. He was a top-ranking real estate agent in his district. As a high achiever in life, Mr. Zee was a risk taker. At 52 he was considered an unlikely candidate for heart attack. But he did have a heart attack, and it was attributed to his Type A personality and his penchant for fast food. Even in the cardiac rehab centre he applied the same Type A personality patterns. Mr. Zee always wanted to do things faster. Naturally, with the intention of completing the program faster, he discreetly increased the speed without the knowledge of the attending nurse. But he was hooked up to a heart monitor; so, an assigned nurse was always monitoring everyone's exercise performances. A slight fluctuation in heart function would be displayed on the computer screen at the monitoring centre. If anyone's heart rate went up, the floor nurse would be notified, and she would go to the patient to take the person's blood pressure and pulse. She then would decide whether it was okay for him to continue, stop or make speed adjustments. Because the nurse would be taking the patient's blood pressure while the patient was walking on the treadmill, she would ask the patient to put his hand on her shoulder.

One day a new nurse was on duty on the floor to take patients' blood pressure every 20 minutes. This nurse, whose name was Nancy, was young, beautiful and voluptuous. On top all those qualities, she wore a rather low-cut blouse, wittingly or unwittingly, exposing her cleavage. When she took Mr. Zee's blood pressure while resting his hand on her bare shoulder, he felt a warm and fuzzy sensation surging through his body, which raised his heart rate a little higher. When that happened, she would turn the speed down.

Because Mr. Zee was having so much fun resting his hand on Nancy's bare shoulder, he would deliberately raise his heart rate, increasing the speed by a few notches. This was sure to raise his heart rate. That was the only way to attract her attention. When his heart rate went up, she would come to take his blood pressure, again. When he saw her coming toward him, he would discreetly change the speed back to the original speed set by her. This game continued for a week. Within this short period, Mr. Zee made remarkable progress in his performance. But suddenly, Nancy didn't return to the floor, crushing Mr. Zee's anticipation of putting his hand on her shoulder. It so happened that she had been replacing another nurse who was on leave of which Mr. Zee didn't have knowledge. One week of hard work led Mr. Zee to graduate a week earlier. This can clearly be attributed to Nancy, albeit she didn't do anything in particular. Her physical presence seems to have inspired the patient to work harder contributing to his wellbeing.

There is a saying that behind every successful man there is a woman. If this be true, Mr. Zee was a case in point. Nancy served as a catalyst for Mr. Zee's rapid progress. Clearly, her magic worked on him, albeit unwittingly. Sadly, however, Nancy wasn't there to see Mr. Zee graduate. She was clearly the inspiration. Mr. Zee's heart rate never went up after Nancy left. I wish she knew the reason. 

CC (1) $\begin{aligned} & \text { This work is licensed under Creative } \\ & \text { Commons Attribution 4.0 License } \\ & \text { DOI: } 10.19080 / J Y P .2019 .07 .555716\end{aligned}$
Your next submission with Juniper Publishers will reach you the below assets

- Quality Editorial service

- Swift Peer Review

- Reprints availability

- E-prints Service

- Manuscript Podcast for convenient understanding

- Global attainment for your research

- Manuscript accessibility in different formats ( Pdf, E-pub, Full Text, Audio)

- Unceasing customer service

Track the below URL for one-step submission https://juniperpublishers.com/online-submission.php 